\title{
ТАЙШИРЫН УСАН ЦАХИЛГААН СТАНЦТАЙ ХОСЛОН АЖИЛЛАХ НАРНЫ ЦАХИЛГААН СТАНЦЫН СУДАЛГАА
}

\author{
Б. Чадраа, Г.Гантөмөр, С.Сайнболд, Ч.Баасандорж, Б.Мэндбаяр, Э.Пүрэвдалай \\ Шинжлэх Ухааны Академи, Физик Технологийн Хүрээлэн \\ Цахим шуудан: chadraamas@yahoo.com
}

\section{Хураангуй}

This paper presents study and results of 10 MW Solar PV plant that will be work with Taishir hydropower plant (as a hybrid system) in Mongolian West region.

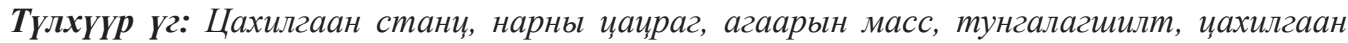
эрчим хүч

\section{ОРШИЛ}

Мянганы хөгжлийн зорилтод суурилсан Үндэсний хөгжлийн цогц бодлого, Монгол улсын засгийн газрын 2012-2016 онд хэрэгжүүлэх үйл ажиллагааны хөтөлбөрт сэргээгдэх эрчим хүчний эх үүсвэрийг үйлдвэрлэх, хөгжүүлэхээр заасан билээ. Энэхүу зорилтуудыг хэрэгжүүлэхээр эрчим хүчний нэгдсэн системийн тухай хууль, сэргээгдэх эрчим хүчний үндэсний хөтөлбөр, Сэргээгдэх эрчим хүчний тухай хууль зэргийг удирдлага болгон одоо ажиллаж байгаа 11 МВТ-ын хүчин чадалтай усан цахилгаан станцыг түшиглэн нарны цахилгаан станц барьж өргөтгөн усан цахилгаан станц, нарны цахилгаан станц хосолсон систем байгуулах техникийн тооцоо боловсруулах санал дэвшүүлээд байна $[1,2]$.

ШУА-ийн Физик технологийн хүрээлэнд боловсруулсан нарны эрчим хүчний кадастрыг үндэс суурь болгон Говь-Алтай аймгийн Тайширын усан цахилгаан станцыг түшиглэн 10 МВт-ын хүчин чадалтай нарны эрчим хүчний станц байгуулах судалгаa, төслийг боловсруулж, хэрэгжүүлэх үе шатандаа ороод ажиллаж байна [3].

Нарны цахилгаан станцын онцлогийг товч дурдвал:

1.Байгалийн шавхагдашгүй нарны эрчим хүчээр ажилладаг, ямар нэгэн хөдөлгөөнт эд анги байдаггүй учир эвдрэл бага, удаан хугацаагаар ажилладаг.

2.Барьж ашиглалтанд оруулах хугацаа маш богино.

3.Барьж байгуулах хугацааг урьдчилан тооцох боломжтой.

4.Засвар үйлчилгээний зардал хамгийн бага.

5.Нарны Фото цахилгаан станцын үндсэн элемент болох нарны модулиудын ажиллах хугацаа 20 жилээс дээш.

6.Усан цахилгаан станцтай хослон ажиллахад сүлжээний ачааллыг тэнцвэржүүлэх боломжтой.

7.Говь-Алтай, Ховд аймгийн иргэдийг ажлын байраар хангах, ядуурлыг бууруулах.

8.Цөлжилтийг сааруулахад илүү тохиромжтой.

9.Ямар нэгэн хортой хог хаягдал болон $\mathrm{CO}_{2}$ ялгаруулдаггүй.

Дээрх онцлогуудыг анхаарч 
Тайширын усан цахилгаан станцыг өргөтгөн 10 МВт-ын нарны цахилгаан станцыг байгуулах судалгаа хийсэн болно [4].

\section{ТАЙШИРЫН УЦС}

Энд нарны станц байгуулах нь дараах үндсэн шалтгаануудтай. Үүнд:

Тайширын усан цахилгаан станц нь усны нөөцөөс шалтгаалан хүчин чадлынхаа гуравны нэг буюу ихэвчлэн нэг генератор ажиллуулж байгаа [5]. Судлаачдын урьдчилсан мэдээгээр сүүлийн жилүүдэд Завхан голын усны нөөц 30\%-иар багассан. Үйлдвэрлэх эрчим хүчний хэмжээ багассанаас нэмэлт дизелийн станц ажиллуулах шаардлагатай болсноор борлуулсан 1 кВт цагийн үнэ зарим үед 600 орчим төгрөгт хүрсний зэрэгцээгээр цөөн цагаар цахилгаан түгээх нь хэрэглэгчдийн шаардлагыг хангадаггүй. Сүүлийн жилүүдэд улсаас 10 тэрбум орчим төгрөгийн татаас авахаар төлөвлөдөг болсон [6].

Тайширын усан цахилгаан станцын техник технологийн Үзүүлэлтүүдийг Хүснэгт 1-ээр харуулав.

ХУснэгт 1. Тайширын УЦС

\begin{tabular}{|c|c|}
\hline Техникийн үндсэн үзүүлэлтүүд & Тайширын УЦС \\
\hline 1. Газрын нэр & Завхан гол \\
\hline 2. Суурилагдсан хүчин чадал & $11 \mathrm{MBT}$ \\
\hline 3. Жилд үйлдвэрлэх эрчим хүч & 37.0 сая кВт* ${ }^{*}$ \\
\hline 4. Усан сангийн нийт эзлэхүүн & 930 сая м ${ }^{3}$ \\
\hline 5. Далангийн өндөр & $190 \mathrm{M}$ \\
\hline 6. Станцын барилгын төрөл & Далангийн ёроолд \\
\hline 7. Генераторууд & $3 * 3.45 \mathrm{MBT}+1 * 0.65 \mathrm{MвT}$ \\
\hline 8. Турбины тоо, төрөл & 4*Франсис \\
\hline 9. Хүчдэл & $10 / 35 / 110$ кВ \\
\hline 10. ЭХ-ний систем & АУЭХС-д багтана. \\
\hline
\end{tabular}

Далангаaс дооших газар нутаг цөлжих хандлагатай болж зарим үед нуур цөөрөм ширгэх болсон. Судлаачдын үзэж байгаагаар экологи, хүрээлэн буй орчинд сөрөг өөрчлөлт гарсан зэрэг шалтгааныг багасгах зорилгоор байгальд ээлтэй нарны эрчим хүчийг ашиглах нь хамгийн зөв арга гэж сонгон авсан болно.

\section{НАРНЫ ЦАХИЛГААН СТАНЦ}

Алтай улиастайн эрчим хүчний системийн нийлбэр ачаалал түүнийг хангаж байгаа эх үүсвэрүүд зэргээс шалтгаалуулан нарны фото цахилгаан станцын чадлыг 10 МВт байхаар сонгов. Тайширын нарны цахилгаан станц нь дор дурдсан үндсэн
Зөвхөн Говь-Алтай аймгийн ойрын ирээдүйн эрчим хүчний хэрэгцээ 20-30 МВт гэж тооцоолсныг нар болон салхины эрчим хүчийг өргөтгөх замаар хангах боломжтой.

Мөн сүлжээний ачааллыг тэнцвэржүүлэх, импортын цахилгааныг багасгах шаардлагатай байгаа зэрэг болно.

төхөөрөмжүүдээс бүрдэнэ:

1.Нарны модулиудаас бүрдсэн тус бүр 2.5 МВт хүчин чадалтай 4 бүлэг (Цахилгааны үзүүлэлтүүдийг тохируулах төхөөрөмж Power Condition Unit-ын хамт) 2.Цахилгаан станцын хяналт 
3.Трансформаторын хэсэг

4.Цахилгаан дамжуулах агаарын шугамд холбогдох хэсэг

Тус бүр 2.5 МВт чадалтай 4 бүлэг нарны модулиуд тус бүрт харгалзах $\mathrm{PCU}$ нь өөртөө инвертер, трансформатор болон сүлжээний удирдлагыг багтаасан. Энэ төхөөрөмжийн тусламжтайгаар Реактив чадлын удирдлагаар хангадаг. 0.4 кВ-ын сүлжээнд холбогдсон нарны цахилгаан станцын хувьд энэ удирдлагыг хэрэглэсэн жишээг Зураг 2-д үзүүлэв. Зургийн дээд хэсгийн графикт реактив чадлын удирдлага хийгдээгүй байх үеийн нарны цахилгаан станцын сүлжээнд нийлүүлж буй хүчдэлийн хэлбэлзлийг харуулсан байна [7].
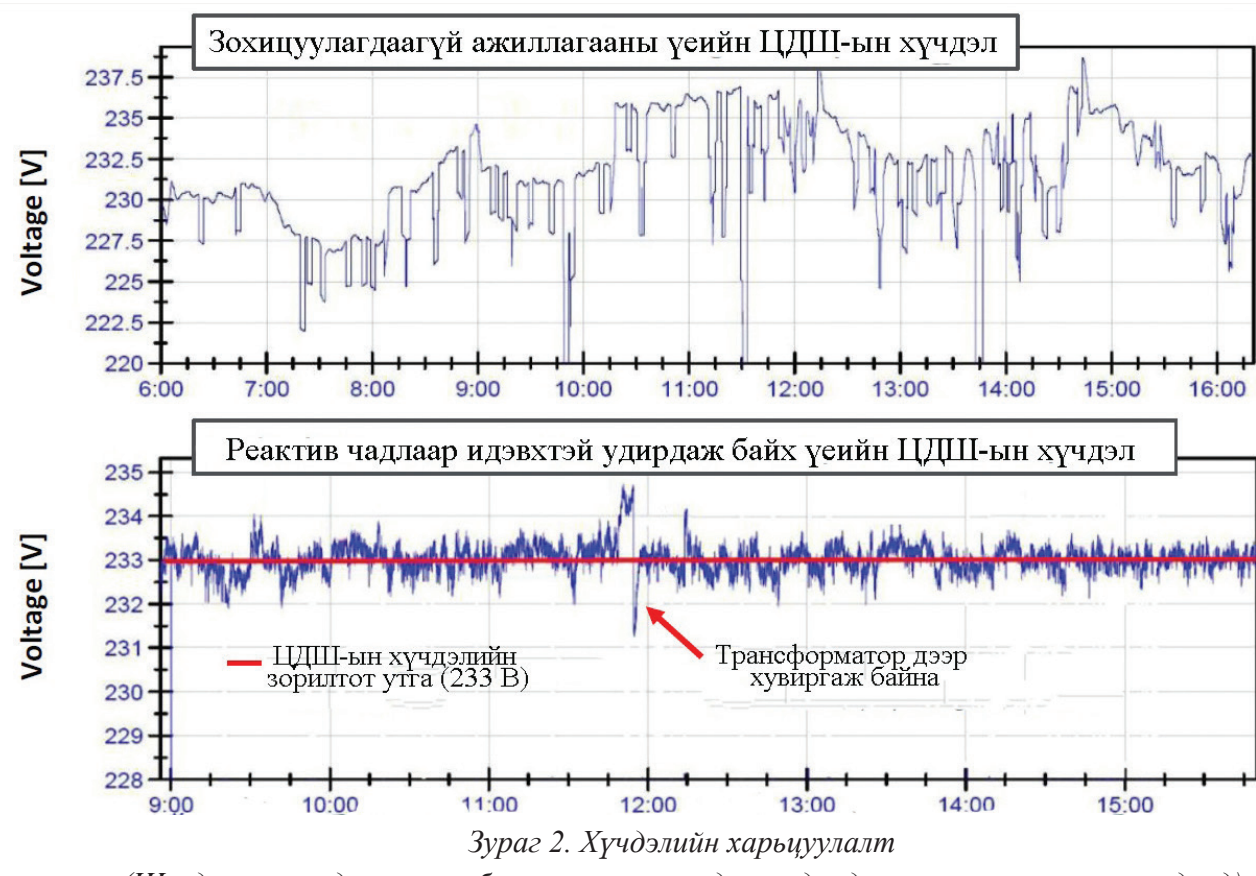

(Шууд сүлжээнд залгасан болон реактив чадльн удирдлага ашигласан тохиолдолд)

Харин доод хэсэгт реактив чадлын удирдлага хийгдэж байх үеийн хүчдэлийн хэлбэлзлийн графикыг харуулсан байна. Эндээс реактив удирдлага нь хүчдэлийг тогтвортой барихад чухал шаардлагатай нь харагдаж байна. Нарны станц нь 22 га талбайд байрлах бөгөөд тус бүр 250 Вт-ын чадалтай 40 мянган ширхэг нарны зай, 10 инвертер болон бусад тоног төхөөрөмжөөс бүрдэнэ [8].

Ус цаг уур орчны шинжилгээний газрын “Алтай” хэмжилтийн станцын олон жилийн мэдээнд боловсруулалт хийсний дүнд энэ нарны станцын хувьд 45 градусын налууд ирэх нарны цацрагийн жилийн дундаж өдрийн энергийн хэмжээ нь 4.6 кВт* ц/м² гэж гарав [9]. Нарны фото цахилгаан станцын үйлдвэрлэх эрчим хүчний хэмжээ нь нарны цацраг, орчны температур зэрэг олон хүчин зүйлээс хамаардаг.

Эдгээр хүчин зүйлүүдээс хамаарсан коэффициентүүдийг ашиглан нарны фото цахилгаан станцын үйлдвэрлэх эрчим хүчийг тооцоолсныг Зураг 3-т үзүүллээ. Зургаас харахад 3 сард үйлдвэрлэх эрчим хүчний хэмжээ хамгийн их байгаа нь тухайн сарын нарны дэлгэцийн хавтгайд ирэх нарны цацрагийн хэмжээ болон орчны дундаж температураас шалтгаалж байна. Энэ тохиолдолд жилд дунджаар 14.1 сая кВт*ц эрчим хүч үйлдвэрлэхээр байна. 


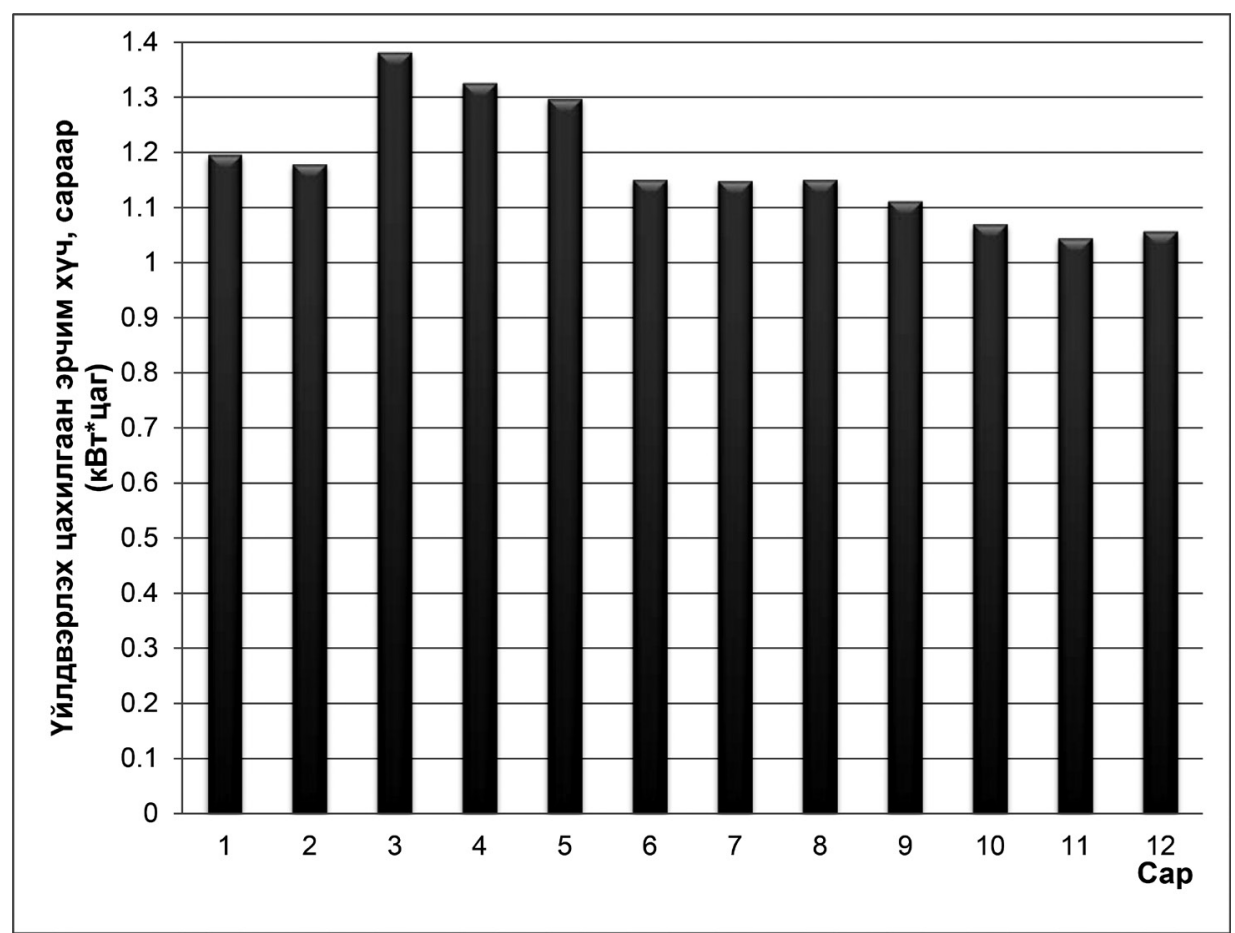

Зураг 3. Тайтирын УЦС-тай хослон ажиллах 10 МВт-ьын Нарны цุахилгаан станцын үйлдвэрлэх цахилгаан эрчим хүч

Өдрийн туршид нарны цахилгаан станц болон усан цахилгаан станц хэрхэн хослон ажиллаж эрчим хүчний хэрэгцээг нөхөх урьдчилсан прогнозыг Зураг 4-т үзүүллээ. Графикаас харахад нарны фото цахилгаан станцын үйлдвэрлэх эрчим хүч өдрийн турш дахь ачааллыг хангах боломжтой байна. Бусад хугацаанд усан цахилгаан станц ажилласнаар усны нөөц шавхагдах эрсдлийг арилгах боломжтой байна.

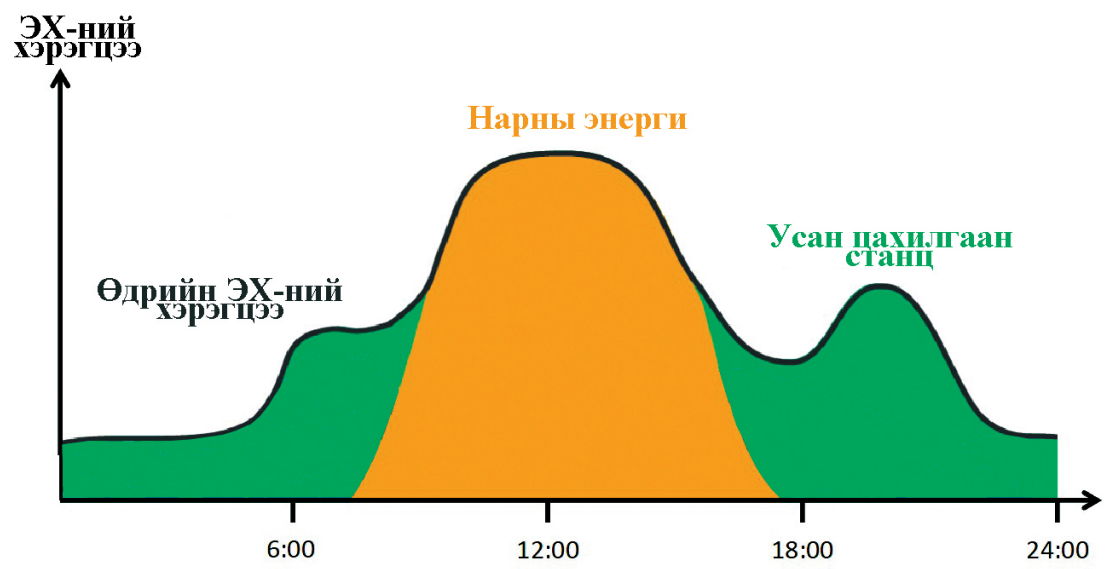

Зураг 4. Усны болон нарны эрчим хүчний станиуудын үйлдвэрлэх эрчим хүч болон эрчим хүчний хэрэглээ

$$
-8-
$$


Төслийн анхны хөрөнгө оруулалт 20 сая ам.доллар. Нарны цахилгаан станцын үйлдвэрлэх 1 кВТ* ц эрчим хүчийг 0.20 ам.доллараар борлуулснаар цахилгаан станцын өртгөө нөхөх хугацаа 8.3 жил гэж эдийн засгийн урьдчилсан тооцоогоор гарав. Хөрөнгө оруулалтын өгөөжийн хувь (return on investment) 1.27 байна. Нөхөлтийн дотоод хувь $11 \%$ (internal rate of return) байна.

\section{ДҮГНЭЛТ}

1. Говь-Алтай аймгийн Тайширын усан цахилгаан станцтай хослон ажиллах $10 \mathrm{MBT}$ нарны цахилгаан станц нь жилдээ ойролцоогоор 14,1 сая.кВт*цаг эрчим хүчийг Алтай-Улиастайн эрчим хүчний системд нийлүүлэх боломжтой.

2. Тайширын УЦС нь 35 кВ болон 110 кВ-ийн шугамтай. Нарны цахилгаан станцыг 35 кВ-ийн шугамд залгаж сүлжээнд нийлүүлэх боломжтой тул цахилгаан дамжуулах шугам шинээр барих шаардлагагүй.

3. Нарны цахилгаан станц нь усан цахилгаан станцтай хосолсон горимоор ажиллах учир эрчим хүчний систем нь уян хатан тогтвортой ажиллах боломжтой. Эдийн засгийн өгөөж өндөртэй гэдэг нь урьдчилсан тооцоогоор гарлаа.

4. Нарны цахилгаан станц байгуулах зардлыг 2.0 доллар/Вт гэж тооцвол анхны хөрөнгө оруулалтын зардал нь 20 сая ам.доллар болж байна. Сэргээгдэх эрчим хүчний хуулийн дагуу $1 \kappa В$ * $^{*}$ цаг эрчим хүчний үнийг 0.2 ам.доллараар борлуулсан тохиолдолд өртгөө нөхөх хугацаа 8.3 жил гэж тооцоогоор гарав.

\section{Ашигласан бүтээлийн жагсаалт}

[1]. Мянганы хөгжлийн зорилтод суурилсан үндэсний хөгжлийн иоги бодлого (2007 он)

[2]. Монгол улсын Засгийн газрын 2012-2016 онд хөгжүүлэх үйл ажсиллагааны хөтөлбөр (2012 $\mathrm{OH})$

[3], [4]. Говь-Алтай аймгийн Тайшир сумылн нутагт байгуулах 10МВт-ын Нарны цахилгаан станиын техник эдийн засгийн үндэслэл. (2013)

[5]. Алтай-Улиастайн эрчим хүчний систем ТӨК, "Тайщирын усан иахилгаан станиын техникийн үзүүлэлтүүд". (2013)

[6]. Говь-Алтай аймгийн Тайшир сумын нутагт байгуулах 10МВт-ын Нарны иахилгаан станцын техник эдийн засгийн үндэслэл. (2013)

[7]. BELECTRIC, "Key issues and measures to address grid integration of renewables at a continually rising renewable share". (2012)

[8]. Говь-Алтай аймгийн Тайтир сумын нутагт байгуулах 10МВт-ын Нарны ияахилгаан станцын техник эдийн засгийн үндэслэл. (2013)

[9]. Ус ияаг уурын орчины шинжилгээний газар, Говь-Алтай аймгийн Тайшир сумын иаг уурын мэдээлэл.

[10]. H.P. Garg, J.Prakash "Solar Energy Fundamentals and Applications" (book, 1997)

[11]. Эрчим хүчний нэгдсэн системийн тухай хууль (2007 он), Сэргээгдэх эрчим хүчний үндэсний хөтөлбөр (2005-2020 он), Сэргээгдэх эрчим хүчний тухай хууль (2007 он)

[12]. Б. Чадраа "Нарны батерей" (ном, 1988 он) 